\title{
MEMBRÁNOVÉ KONTAKTORY A JEJICH APLIKAČNÍ POTENCIÁL
}

\section{Václav DurĎák, Marek Martinec a RADEK ŠKAROHLÍD}

Ústav chemie ochrany prostredi, Fakulta technologie ochrany prostředí, Vysoká škola chemicko-technologická v Praze, Technická 5, 16628 Praha 6

durdakv@vscht.cz

Došlo 11.10.21, přijato 1.11.21.

Klíčová slova: membránové kontaktory, dutá vlákna, membránová extrakce, membránová absorpce

- https://doi.org/10.54779/chl20220035

\section{Obsah}

1. Úvod

2. Membránové kontaktory

3. Přenos hmoty v membránových kontaktorech

4. Design a výroba membránových kontaktorů

5. Použití v provedení plyn-kapalina

6. Použití v provedení kapalina-kapalina

7. Závěr

\section{1. Úvod}

V současné době je kladen celospolečenský důraz na udržitelnost, oběhové hospodářství a obnovitelné zdroje. Tento trend se projevuje též v průmyslu, kde je snahou snižování energetické a materiálové náročnosti procesů a jejich celková intenzifikace pro zvýšení účinnosti, snížení ekonomických nákladů, zvyšování bezpečnosti práce a redukci ekologických havárií ${ }^{1-3}$. Jednou z možností, jak intenzifikace dosahovat, je implementace membránových technologií, kupř́kladu reverzně osmotické, ultrafiltrační a mikrofiltrační membrány znamenaly revoluci při výrobě pitné vody ${ }^{4-6}$.

Na rozdíl od filtračních membrán nebo reverzně osmotických, lze však membrány využívat i jako zařízení pro sdílení hmoty nebo separaci, jako náhradu konvenčních energeticky náročných kolonových nebo míchaných zařízení. Tato zařízení jsou označována jako membránové kontaktory a dle způsobů jejich použití se dělí na membránové absorbéry a membránové extraktory ${ }^{7-9}$.

V konvenčním zařízení na sdílení hmoty a separaci dochází $\mathrm{k}$ přenosu hmoty mezi dvěma omezeně mísitelnými fázemi jejich vzájemným intenzivním kontaktem bud' $\mathrm{v}$ míchaných nebo kolonových zařízeních. Naproti tomu $\mathrm{v}$ membránových kontaktorech $\mathrm{k}$ mísení dvou fází nedochází a mezifázová plocha vzniká na rozhraní membrány v jejích mikropórech ${ }^{10,11}$

Obecně mají membránové kontaktory řádově větší aktivní plochu vztaženou na stejnou jednotku objemu zařízení $^{12}$.

Cílem tohoto příspěvku je blíže představit techniku membránových kontaktorů s kritickým zhodnocením jejich výhod a nevýhod, a to včetně představení aplikačního potenciálu těchto zařízení a následně také i některých vybraných již realizovaných provozních jednotek.

\section{Membránové kontaktory}

Přestože mohou membránové kontaktory vypadat podobně jako jiná membránová zařízení, jejich funkce je zásadně odlišná. Většinou se jedná o mikroporézní neselektivní membrány. Ty mohou být deskové, ale v převážné většině případů se využívá úzkých, či přímo kapilárních, dutých porézních vláken. Stěna membrány je protkaná drobnými kapilárami (mikropóry), které spojují vnitřní a vnější prostor vláken a vytváří tak komunikační kanál umožňující sdílení hmoty (viz obr. 1). Materiály vláken jsou nejčastěji hydrofobní polymery, jako je polypropylen (PP), polyethylen (PE), polytetrafluorethylen (PTFE), perfluoralkoxyalkany (PFA) nebo polyvinylidenfluorid (PVDF). Použitelné jsou však i hydrofilní polymery nebo

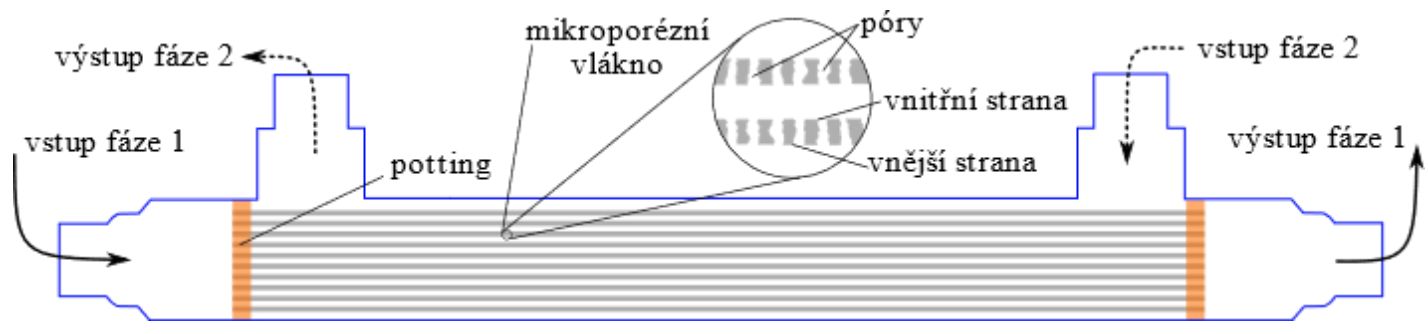

Obr. 1. Membránový kontaktor s dutými mikroporézními vlákny s paralelním uspořádáním toku fází 
př́padně anorganické materiály či keramické hmoty ${ }^{7,13}$ Jednotlivá vlákna jsou uspořádána do svazků, jež jsou vlepeny v modulu pomocí adhesivního lepidla, které zároveň odděluje prostor mezi fázemi na vstupu a výstupu fází do modulu. Nejjednodušší provedení membránového kontaktoru s dutými vlákny (obr. 1) je opatřeno vstupem a výstupem na opačných koncích modulu pro jednu z fází proudící uvnitř vláken a na stěně modulu vstupem a výstupem pro druhou fázi, která proudí vně vláken a umožňuje tak paralelní tok fází. Existují však také designová řešení umožňující kolmý tok se středovou perforovanou nátokovou a sběrnou trubkou a přepážkou ${ }^{14}$.

Membrána v kontaktoru funguje jako pasivní bariéra umožňující nedisperzní kontakt fází. V prŕípadě membránového absorbéru se jedná o kontakt plynné a kapalné fáze a $\mathrm{v}$ př́ípadě membránového extraktoru o dvě nemísitelné kapalné fáze (vodná a organická). Mezifázové rozhraní je imobilizováno $\mathrm{v}$ pórech membrány vyplněných jednou $\mathrm{z}$ fází. U hydrofobních membrán je v pórech bud' plynná, nebo organická fáze. Díky tomu, že není nutné fáze mezi sebou mísit, odpadá i nutnost jejich následovného dělení. $\mathrm{V}$ tomto uspořádání lze $\mathrm{s}$ výhodou provozovat procesy založené na kontaktu fází, jako je absorpce plynů, stripování plynů, extrakce mezi dvěma kapalnými fázemi $\operatorname{apod}^{9,15-17}$.

Přri smáčení pórů jednou $\mathrm{z}$ fází hraje důležitou roli smáčivost materiálu membrány. Smáčení je vyjadřováno pomocí kontaktního úhlu $\theta$, jenž udává stupeň smáčení při interakci pevné látky a kapaliny. Kontaktní úhel se měří mezi tečnou povrchu kapky v místě, kde se kapka dotýká smáčeného povrchu a samotným povrchem, viz obr. 2. Materiály, jejichž kontaktní úhel měřený s vodou je menší než $90^{\circ}$, budou hydrofilními membránami a kapalná fáze bude $\mathrm{v}$ takových případech smáčet povrch i póry. Materiály, jež mají s vodou kontaktní úhel větší než $90^{\circ}$, jsou hydrofobní a jejich povrch vodnou fází smáčen nebude ${ }^{18,19}$. $\mathrm{Z}$ dat uvedených $\mathrm{v}$ literatuře ${ }^{9}$ vyplývá, že $\mathrm{z}$ běžně používaných materiálů pro výrobu hydrofobních membrán má největší kontaktní úhel s vodou PTFE $\left(112^{\circ}\right)$, druhý největší kontaktní úhel s vodou má PP $\left(108^{\circ}\right)$.

Hydrofobní membrány $\mathrm{s}$ kontaktním úhlem větším než $90^{\circ}$ nebudou přirozeně smáčené vodou, stejně tak nebudou smáčeny ani jejich mikropóry, které tak zůstanou vyplněné vzduchem při kontaktu vodné a plynné fáze, a $\mathrm{v}$ prrípadně kontaktu vodné a organické fáze budou póry zaplněné organickou fází. Na straně fáze, která membránu nesmáčí, musí být aplikován mírný přetlak. Díky přetlaku je smáčející fáze udržována uvnitř mikropórů. Tímto způsobem je zajištěn rovnovážný nedisperzní kontakt dvou fází v mikropórech membrány. Přetlak však nesmí překročit určitou kritickou hodnotu tlaku $\Delta P_{\mathrm{C}}$, kdy je rovnovážný

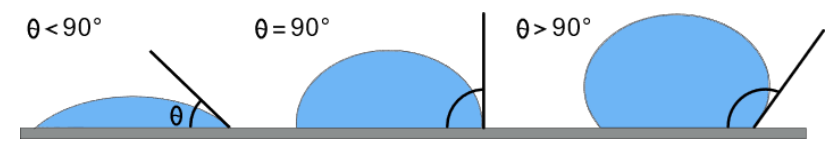

Obr. 2. Znázornění kontaktního úhlu pro rozdílně smáčený povrch stav narušen a nesmáčející fáze začne pronikat do vláken. Tento kritický přetlak je matematicky popsán ${ }^{18}$ Youngovou-Laplaceovou rovnicí (1):

$$
\Delta P_{\mathrm{C}}=\frac{2 \gamma \cos \theta}{r}
$$

kde $\gamma\left[\mathrm{N} \mathrm{m}^{-1}\right]$ je povrchové napětí, $\theta\left[^{\circ}\right]$ je kontaktní úhel a $r$ [m] je poloměr póru (prưřez póru aproximován kruhem). Na př́kladu systému, kde dochází v membráně s velikostí pórů $0,03 \mu \mathrm{m}$ ke kontaktu vzduchu a vody, lze výpočtem zjistit, že pro hodnoty kritického průrazového tlaku platí $\Delta P_{\mathrm{C}}>2 \mathrm{MPa}$. Póry membrány v takovém systému zůstanou vyplněné vzduchem, pokud je pro přetlak vody $(\Delta P)$ splněna podmínka: $0<\Delta P<\Delta P_{\mathrm{C}}$. Př́i splnění této podmínky lze provozovat membránový kontaktor v nedisperzním stavu i při změně ostatních provozních parametrů, jako jsou např́klad rychlosti průtoků fází nebo teplota.

Obdobné podmínky platí také pro systém, kde jsou v kontaktu dvě vzájemně nemísitelné kapalné fáze (vodná a organická). Pouze s tím rozdílem, že v rovnici (1) symbol $\gamma$ reprezentuje mezifázové napétí mezi vodnou a organickou fází. Póry jsou $\mathrm{v}$ tomto prrípadě vyplněny organickou (hydrofobní) fázi $1^{13,20}$.

Mezi další možnosti provedení spadá také systém, kde jsou na obou stranách membrány uvažovány vodné fáze, jež nesmáčí polymer, jehož póry tak zůstanou vyplněné vzduchem a dochází tak $\mathrm{k}$ přenosu těkavé složky skrze póry vyplněné vzduchem $z$ jedné fáze do druhé. V takových př́padech se jedná o tzv. plynové membrány. Lze je s výhodou uplatnit např́klad při odstraňování amoniaku či sulfanu $\mathrm{z}$ vod $^{21-24}$. Hlavní výhody a limity použití membránových kontaktorů jsou shrnuty v tab. I.

\section{Přenos hmoty v membránových kontaktorech}

V membránových kontaktorech je jedna $\mathrm{z}$ fází imobilizována $\mathrm{v}$ pórech membrány, proto $\mathrm{v}$ nich nedochází ke konvektivnímu toku. Přenos hmoty se tak děje výhradně difuzí skrze imobilizovanou fázi na základě koncentračního gradientu ve směru poklesu koncentrace. $Z$ toho důvodu vytvář́ imobilizovaná fáze dodatečný odpor proti přenosu hmoty v porovnání s tradičními disperzními systémy. Odpor proti přenosu hmoty je vyjádřen jako převrácená hodnota koeficientu přestupu hmoty. $\mathrm{V}$ membránových kontaktorech je celkový odpor proti přenosu hmoty vyjádřen pomocí tří dílčích odporů v řadě za sebou. Dva $\mathrm{z}$ nich popisují odpor proti přestupu hmoty na fázovém rozhraní a další odpor proti přenosu hmoty skrze mikropóry membrány. Pro aplikace, kde je v kontaktu plyn-kapalina, proudí plyn po vnější straně vláken a kapalina je uvnitř, je jeho odpor dán následující relacíi ${ }^{13}$ :

$$
\frac{1}{K_{0} d_{\text {out }}}=\frac{1}{k_{\mathrm{os}} d_{\text {out }}}+\frac{1}{\mathrm{H} k_{\mathrm{mo}} d_{\mathrm{lm}}}+\frac{1}{\mathrm{H} k_{\mathrm{wt}} d_{\text {in }}}
$$

kde $K_{0}\left[\mathrm{~m} \mathrm{~s}^{-1}\right]$ je celkový koeficient prostupu hmoty, $k_{\mathrm{os}}$ $\left[\mathrm{m} \mathrm{s}^{-1}\right]$ koeficient přestupu hmoty na vnější straně vláken, 
$k_{\mathrm{mo}}\left[\mathrm{m} \mathrm{s}^{-1}\right]$ koeficient přestupu hmoty skrze mikropóry, $k_{\mathrm{wt}}$ $\left[\mathrm{m} \mathrm{s}^{-1}\right]$ koeficient přestupu hmoty na vnitřní straně vláken, $d_{\text {in, }}, d_{\mathrm{lm}}$ a $d_{\text {out }}[\mathrm{m}]$ jsou vnitřní průměr, logaritmický průměr a vnější průměr vlákna a $\mathrm{H}\left[\mathrm{Pa} \mathrm{m}^{3} \mathrm{~mol}^{-1}\right]$ je Henryho konstanta.

Obdobně lze matematicky vyjádřit odpor proti přenosu hmoty, kde jsou v kontaktu dvě kapalné fáze, použitím rozdělovacího koeficientu $m_{i}$ místo Henryho konstanty, kde $m_{i}$ je definován jako poměr koncentrace látky v organické a vodné fázi. Pro hydrofobní membránu, kde je organická fáze na vnější straně vláken a hnací síla vychází z koncentrace $\mathrm{v}$ organické fázi, je popis odporu proti přenosu hmoty dán rovnicí (3) a dále lze popsat stejný př́pad, kdy hnací síla vychází z koncentrace ve vodné fázi. Popis odporu proti přenosu hmoty je potom dán rovnicí (4) (cit. $\left.{ }^{20}\right)$ :

$$
\begin{aligned}
& \frac{1}{K_{0} d_{\text {in }}}=\frac{1}{k_{\mathrm{os}} d_{\text {out }}}+\frac{1}{k_{\mathrm{mo}} d_{\mathrm{lm}}}+\frac{m_{i}}{k_{\mathrm{wt}} d_{\mathrm{in}}} \\
& \frac{1}{K_{\mathrm{w}} d_{\mathrm{in}}}=\frac{1}{k_{\mathrm{wt}} d_{\mathrm{in}}}+\frac{1}{m_{i} k_{\mathrm{mo}} d_{\mathrm{lm}}}+\frac{1}{m_{i} k_{\mathrm{os}} d_{\text {out }}}
\end{aligned}
$$

kde $K_{0}$ a $K_{\mathrm{w}}\left[\mathrm{m} \mathrm{s}^{-1}\right]$ jsou celkové koeficienty prostupu hmoty, $k_{\mathrm{os}}, k_{\mathrm{mo}}$ a $k_{\mathrm{wt}}\left[\mathrm{m} \mathrm{s}^{-1}\right.$ ] jsou koeficienty přestupu hmoty a $d_{\text {in }}, d_{1 \mathrm{~m}}$ a $d_{\text {out }}[\mathrm{m}]$ průměry vlákna, $m_{i}$ je bezrozměrný rozdělovací koeficient mezi vodnou a organickou fází.

Aby uvedené rovnice (2) - (4) platily, musí být splněny následující předpoklady: systém je v ustáleném stavu, na mezifázovém rozhraní je ustanovena rovnováha, velikost pórů a vlastnosti membrány jsou $\mathrm{v}$ celé membráně jednotné, zakřivení mezifázového rozhraní v pórech neovlivňuje výrazným způsobem rychlost přenosu hmoty, přenos hmoty je dostatečně popsán aproximativním modelem vycházejícím z filmové teorie ${ }^{20}$, neprobíhá žádný transport hmoty skrze neporézní část membrány, fáze, jež jsou v kontaktu, jsou navzájem nemísitelné a rovnovážná distribuce rozpuštěné látky je konstantní v celém zkouma- ném rozsahu koncentrací.

$Z$ rovnic (3) a (4) je dále patrné, že pro vysoké hodnoty $m_{i}$ se stává hlavním odporem pro přenos hmoty hraniční vrstva u fázového rozhraní na straně vodné fáze. Naopak pro velmi nízké hodnoty $m_{i}$ se stávají dominantními odpory proti přenosu hmoty hraniční vrstva na straně organické fáze a membrány.

Koeficient prestupu hmoty skrze membránu $k_{\text {mo }}$ je jednak funkcí difuzního koeficientu fáze, která vyplňuje póry, ale zároveň také parametrů membrány, zejména těch vyjadřujících vlastnosti pórů a lze jej matematicky vyjádřit následující rovnicíi ${ }^{20}$.

$$
k_{\mathrm{mo}}=\frac{2 D \varepsilon_{\mathrm{M}}}{\tau_{\mathrm{M}}\left(d_{\mathrm{out}}-d_{\text {in }}\right)}
$$

kde $D\left[\mathrm{~m}^{2} \mathrm{~s}^{-1}\right]$ je difuzivita ve fázi vyplňující póry, $\varepsilon_{\mathrm{M}}$ je bezrozměrná porozita membrány, $\tau_{\mathrm{M}}$ je bezrozměrná tortuozita membrány a $d_{\text {in }}$ a $d_{\text {out }}[\mathrm{m}]$ vnitřní a vnější průměr membrány.

V př́padech, kdy je morfologie membrány složitější nebo se jedná o kompozitní membrány, nebude předchozí vztah platit a koeficient $k_{\mathrm{mo}}$ musí být vyjádřen jiným způsobem nebo určen experimentálně.

Přenos hmoty je zajišt'ován kontinuálně $\mathrm{v}$ celé délce membránového kontaktoru a jeho celkovou účinnost lze vyjádřit pomocí parametru rychlosti prenosu hmoty $(R)$ pro každou složku. Jeho obecný popis lze vyjádřit následujícím způsobem ${ }^{9}$ :

$$
R=K_{0} A\left(c_{i, \text { out }}-c_{i, \text { in }}\right)
$$

kde $R\left[\mathrm{~mol} \mathrm{~s}^{-1}\right]$ je rychlost přestupu hmoty, $K_{0}\left[\mathrm{~m} \mathrm{~s}^{-1}\right]$ je celkový koeficient prostupu hmoty, $A\left[\mathrm{~m}^{2}\right]$ je plocha vnější strany membrány, $c_{i, \text { out }}\left[\mathrm{mol} \mathrm{m}^{-3}\right]$ je koncentrace složky $i$ ve fázi na vnější straně vláken a $c_{i, \text { in }}\left[\mathrm{mol} \mathrm{m}^{-3}\right]$ je koncentrace složky $i$ ve fázi uvnitř vláken. Např́klad při membrá-

\begin{tabular}{|c|c|}
\hline Výhody & Nevýhody \\
\hline Nedochází k disperzi fází & Zvýšený odpor proti přenosu hmotu daný membránou \\
\hline Není potřebné dělení fází & $\begin{array}{l}\text { Provoz možný pouze při tlaku nižším, než je kritický } \\
\text { průrazný tlak }\end{array}$ \\
\hline Neobsahuje pohyblivé části & Možná nižší životnost použitých polymerů \\
\hline Snadný up-scale & Vyšší náklady \\
\hline Snadnější obsluha & Zanášení membrán \\
\hline Možnost použití kapalin s podobnou hustotou & Preferenční toky \\
\hline \multicolumn{2}{|l|}{ Nedochází k přeplňování ani pěnění } \\
\hline \multicolumn{2}{|l|}{ Násobná plocha vztažená na jednotku objemu zařízení } \\
\hline \multicolumn{2}{|l|}{ Snadno definovaná a neměnná mezifázová plocha } \\
\hline $\begin{array}{l}\text { Možnost použití vertikálně i horizontálně bez narušení } \\
\text { účinnosti procesu }\end{array}$ & \\
\hline
\end{tabular}
nové extrakci, kdy proudí po vnější straně vláken organic-

Tabulka I

Souhrn výhod a nevýhod membránových kontaktorů 
ká fáze a uvnitř vláken voda, je $c_{i, \text { out }}$ koncentrace složky $i$ $\mathrm{v}$ organické fázi a $c_{i, \text { in }}$ její koncentrace ve vodě.

Z uvedených vztahů vyplývá, že největší odpor přenosu hmoty může nastávat bud' nedostatečnou difuzí látek skrze póry membrány, nebo nedostatečnou výměnou hmoty v okolí hraniční vrstvy mezifázového rozhraní. Difuzi $\mathrm{v}$ pórech lze ovlivnit pouze volbou materiálu, zatímco dostatečnou výměnu hmoty blízko fázového rozhraní lze ovlivnit správným designem modulu.

\section{Design a výroba membránových kontaktorů}

Primární snahou při výrobě membránových kontaktorů je dosažení maximálního kontaktu dvou zájmových fází. Hlavní funkční jednotkou membránového kontaktoru je samotná membrána, nicméně rozhodující vliv na celkovou účinnost kontaktoru má zejména vnitřní design uložení membrány. Protože $v$ současné době jsou pro účely membránových kontaktorů využívána zejména dutá mikroporézní vlákna, je snahou jednotlivá vlákna v kontaktorech uspořádat do takové podoby, aby měla celá jednotka co nejlepší hydrodynamické vlastnosti pro obě fáze. Jak totiž vyplývá z rovnic uvedených v předchozí kapitole, celkový přenos hmoty je závislý na dílčích koeficientech přenosu hmoty v každé z fází. Se zvětšujícím se rozměrem kontaktoru a $\mathrm{s}$ tím souvisejícím větším počtem individuálních vláken je usměrňování toku uvnitř modulu zásadnější než pro malé laboratorní testovací moduly. Zároveň je design podstatný pro efektivitu velkovýroby modulů ${ }^{7,14}$.

Postup při designu a následné výrobě se odvíjí zejména od rozhodnutí, která $\mathrm{z}$ fází má být přiváděna do vláken a která po jejich vnější straně, a dále potom jaký směr toku fází je požadován, zda paralelní nebo kolmý k ose vláken. Od toho se dále pokračuje $\mathrm{k}$ výběru vhodné membrány s ohledem na její dostatečnou chemickou odolnost, vnitřní a vnější průměr a velikost pórů. Pro aplikace, kde dochází ke kontaktu plynné a kapalné fáze, se volí obecně vlákna užší, tenčí a s menšími póry a plynná fáze proudí většinou uvnitř vláken. Naopak pro aplikace, kde jsou v kontaktu dvě kapalné fáze, se většinou volí spíše vlákna širší pro dosažení co nejnižší tlakové ztráty v modulu ${ }^{7,8}$.

Po výběru vhodného materiálu membrány se provede design celého modulu. Nejjednodušším je válcový tvar, ve kterém je umístěn svazek vláken a tok je paralelní ${ }^{14}$. Takové moduly jsou zároveň snadné pro výrobu. Nevýhodou tohoto uspořádání však je, že při narůstajícím počtu vláken není zajištěno rovnoměrné uspořádání vláken a jejich stejná délka, vznikají tak místa s větší a menší hustotou vláken, čímž dochází při provozu $\mathrm{k}$ tvorbě preferenčních toků a s tím související pokles rovnoměrné distribuce toku fáze na vnější straně vláken ${ }^{7,10,16,25}$.

Pro překonání těchto nedostatků byly od dob prvního designu $^{26}$ navrženy různé formy modulů pro dosažení kolmého toku fází vưči sobě ${ }^{7,14}$. Bylo totiž zjištěno, že kolmý tok fáze na vnější straně vláken výrazně zlepšuje přenos hmoty v modulu v porovnání s paralelním tokem ${ }^{7,9,26}$. Výroba modulů s kolmým tokem je však stále nákladnější než výroba modulů s paralelním uspořádáním toku fází, a pro- to je i v současné době, zejména pro výrobu menších modulů či v menším objemu výroby, využíváno stále modulů s paralelním uspořádáním. Pro překonání problémů s tvorbou preferenčních toků a zajištění kolmého toku byl vymyšlen koncept fabrikace dutých vláken podobným způsobem, jako jsou vyráběny tkaniny, jen s tím rozdílem, že osnova je zde tvořena dutými vlákny a útek tvoří nitě z chemicky odolného materiálu, které zároveň vytvárí prostor mezi jednotlivými vlákny. Tyto tkaniny $\mathrm{z}$ dutých vláken jsou následně navinuty na centrální nátokovou perforovanou trubku ${ }^{14}$.

Kolmého toku je dosahováno dvojím způsobem. $\mathrm{V}$ prvním případě je odtok umístěn $\mathrm{v}$ plášti modulu a tak je fáze přitékající nátokovou středovou trubkou nucena proudit směrem k plášti, čímž kolmo obtéká vlákna uložená $\mathrm{v}$ modulu podélně s nátokovou trubkou. $\mathrm{V}$ druhém, efektivnějším př́ípadě, je středová trubka rozdělena na dvě části (nátokovou a odtokovou) vložením zátky doprostřed a modul je tak doplněn ve středu přepážkou. Nátok je realizován v první polovině středové trubky, kdy je tok fáze dále usměrňován směrem $\mathrm{k}$ plášti díky přepážce vložené doprostřed modulu. Poté co u pláště obteče přepážku, je tok $\mathrm{v}$ druhé polovině modulu zase přiváděn do středové odtokové trubky. Díky tomuto uspořádání je zajištěn kolmý tok $\mathrm{k}$ podélně uloženým vláknům ${ }^{14}$. Př́i výrobě modulů jsou v současné době častěji aplikovány také postupy, kdy jsou vlákna postupně navíjena na otáčející se středovou trubku ve vrstvách nad sebou, kdy vznikají helikální struktury, nebo jsou aplikovány takové způsoby výroby, aby helikální struktura byla prímo produktem vzniku samotných vláken. $\mathrm{V}$ obou prŕpadech vznikají moduly, které mají díky vznikajícím vírivým tokům uvnitř vláken ještě lepší koeficient přestupu hmoty v mezní vrstvě fáze proudící uvnitř vláken ${ }^{14,26}$.

Při designu membránových modulů lze využít také rámových konstrukcí, kdy jsou vlákna napnuta v konstrukci rámu a jednotlivé rámy jsou následně skládány nad sebe vždy v další vrstvě kolmo na vrstvu předchozí. $\mathrm{V}$ tomto designu lze využít možnost kontaktu tř́ fází a integrovat tak do modulu další technologický krok, naprríklad spojit absorpci s následným stripováním, př́padně využít více různých extrakčních činidel pro dělení směsi látek $\mathrm{s}$ rozdílnou afinitou $\mathrm{k}$ použitým extrakčním činidlům $^{7,13}$. Design jednotlivých modulù se zároveň čím dál více liší dle zamýšlené aplikace a vznikají různé speciální integrované systémy zahrnující i více dílčích modulů zapojených v sériích či paralelních větvích současně7.

\section{Použití v provedení plyn-kapalina}

Jednu z prvních aplikací membránových kontaktorů pro kontakt kapaliny a plynu lze najít $\mathrm{v}$ biomedicíně, kde již v roce 1971 autoři popisují použití nových materiálů zkoumaných pro okysličování krve a odstraňování oxidu uhličitého jako zařízení na podporu života ${ }^{27}$. Zatím neúspěšně byly membránové kontaktory zkoumány také pro možné získávání rozpuštěného kyslíku ve vodě a dýchání pod vodou ${ }^{28,29}$. Neúspěšné tyto pokusy byly zejména pro- 
to, že ve vodě je kyslíku relativně malé množství. Konceptu odstraňování kyslíku z vody pomocí membránových kontaktorů se však využívá například pro výrobu ultra čisté vody ${ }^{30}$. Dále byly membránové kontaktory využity při získávání dusíku a kyslíku ze vzduchu absorpcí do vhodného média ${ }^{31}$.

Jiným velkým odvětvím je separace oxidu uhličitého ze vzduchu nebo $\mathrm{z}$ odpadních plynů využitím membránových kontaktorù $^{17,32-38}$. Zkoumány byly možnosti odstraňování vlhkosti ze vzduchu ${ }^{39}$ nebo naopak jeho ovlhčení ${ }^{40}$. Další potenciál představují také pro odstraňování těkavých složek $\mathrm{z}$ vod ${ }^{41}$, nebo $\mathrm{k}$ odstraňování amoniaku a oxidu siřičitého ze vzduchu jako potenciálně uplatnitelná technika $\mathrm{k}$ jejich separaci $\mathrm{z}$ odpadních plynư ${ }^{42}$. Dále je lze aplikovat jako zařízení pro prevenci úniku těkavých látek do ovzdušsi ${ }^{43}$. Jako průmyslové aplikace jsou instalovány zejména jednotky odstraňující rozpuštěné plyny z vod pro výrobu ultra čistých $\operatorname{vod}^{7,9}$ nebo zařízení pro odstraňování amoniaku $\mathrm{z} \operatorname{vod}^{15}$.

\section{Použití v provedení kapalina-kapalina}

Stejně jako $\mathrm{v}$ předchozím případě, i v provedení pro kontakt dvou kapalných fází představují membránové kontaktory široký aplikační potenciál. Vyzkoušeny byly laboratorně zejména pro čištění odpadních vod nebo odstraňování či znovuzískávání cenných látek z odpadních vod, typicky zejména kovi̊.

Jedna z prvních aplikací membránových extraktorů byla v roce 1979 pro získávání stopových množství organických látek z vod za účelem jejich analytického stanove$n^{4}{ }^{44}$. Následovaly experimentální práce zaměřené na odstraňování organických látek $\mathrm{z}$ odpadních vod za využití modelových kontaminantů 2-chlorfenolu, nitrobenzenu, toluenu a akrylonitrilu ${ }^{45}$. Jejich další možné využití je směřováno $\mathrm{k}$ extrakci penicilinu $\mathrm{z}$ vodného roztoku, kdy byla porovnávána mezi sebou dvě extrakční činidla Aliquat 336 a Amberlite La-2 (cit. ${ }^{46}$ ). Jiní autoři zkoumali získávání penicilinu podobným způsobem, kde se zaměřovali zejména na popsání odporu proti přenosu hmoty ${ }^{47} \mathrm{~V}$ další studii byla zkoušena membránová extrakce k odstraňování pesticidů $\mathrm{z}$ vod $^{48}$.

Největší množství literárních zdrojů však zatím uvádí experimentální ověření membránových extraktorů pro extrakci kovů jako možnosti jejich zpětného získávání z odpadních proudů nebo odstraňování nežádoucích toxických kovů z odpadních proudů za účelem snížení toxicity odpadư $^{49,50}$. Např́klad se jedná o selektivní získávání germania z odpadů vznikajících při zpracování uhlí nebo zinku, kdy autoři zjistili, že v jejich uspořádání je možné selektivně získávat germanium s účinností přesahující $98 \%$ $\left(\right.$ cit. $\left.^{51}\right)$. Jiní autoři odzkoušeli selektivní odstraňování zinku z vodného roztoku směsi zinku a železa vznikající při procesu galvanického pokovování ${ }^{52}$. Zjistili, že zinek lze selektivně odstraňovat ze vznikající odpadní vody a vracet do procesu, což může znamenat výrazné materiálové i finanční úspory. I další autoři znovuzískali zinek $\mathrm{z}$ odpadní vody po galvanizaci ${ }^{52}$. Jiným př́kladem může být odstraňování arsenu z vody, kdy autoři ${ }^{53}$ využili extrakční činidlo Aliquat-336 a při nejlepších podmínkách dosáhli účinnosti až 70 \%. Další možnosti jsou využití membránových extraktorů $\mathrm{k}$ znovuzískávání mědi ${ }^{54}$, př́ipadně zlata ${ }^{55}$, nebo odstraňování chromu a mědi $\mathrm{Z}$ průmyslových odpadních vod ${ }^{56}$. Popsané průmyslové aplikace jsou zejména zařízení na selektivní extrakci kovů $\mathrm{Z} \operatorname{vod}^{15}$.

\section{Závěr}

Membránové kontaktory jsou aparáty pro sdílení hmoty a oproti jinak běžně používaným kolonovým nebo míchaným zařízením představují výraznou úsporu energií, materiálu a místa a jsou tak ideálním technickým prostředkem pro intenzifikaci průmyslových procesů pro sdílení hmoty. Jejich hlavní výhodou oproti kolonovým nebo míchaným zařízením je zejména mnohem jednodušší celkové technické řešení bez nutnosti disperze fází mezi sebou. Tím odpadá i následná nutnost fáze oddělit. Díky tomu, že je jejich funkčnost nezávislá na gravitaci, lze v nich používat i kombinace látek, které by $\mathrm{v}$ zařízeních vyžadujících gravitační dělení fází nebyly možné a zároveň je možné umístit je jak horizontálně, tak vertikálně bez omezení jejich výkonu. Protože mají násobně větší povrch vztažený na objem zařízení, mají celkově mnohem menší nároky na prostor než konvenční zařízení. Díky této konstrukci byly od dob svého prvního představení jako konceptu vyzkoušeny pro mnoho různých aplikací zahrnujících odstraňování toxických látek z plynů a vod, zbavování rozpuštěných plynů pro účely výroby ultra čistých vod, nebo naopak sycení kapalin plynem at' už pro účely potravinářského průmyslu, nebo jako zařízení pro mimotělní okysličování krve. Potenciál využití membránových kontaktorů v průmyslových aplikacích je proto velmi slibný.

\section{LITERATURA}

1. Van Gerven T., Stankiewicz A.: Ind. Eng. Chem. Res. 48, 2465 (2009).

2. Sgroi M., Vagliasindi F. G. A., Roccaro P.: Curr. Opin. Environ. Sci. 2, 20 (2018).

3. Geissdoerfer M., Savaget P., Bocken N. M. P., Hultink E. J.: J. Clean. Prod. 143, 757 (2017).

4. Hailemariam R. H., Woo Y. C., Damtie M. M., Kim B. C., Park K.-D., Choi J.-S.: Adv. Colloid Interface Sci. 276, 102100 (2020).

5. Mallevialle J., Odendaal P. E., Wiesner M. R.: Water treatment membrane processes. American Water Works Association, 1996.

6. Anis S. F., Hashaikeh R., Hilal N.: Desalination 452, 159 (2019).

7. Pabby A. K., Wickramasinghe S. R., Sirkar K. K., Sastre A.-M.: Hollow Fiber Membrane Contactors: Module Fabrication, Design and Operation, and Potential Applications. CRC Press, Boca Raton 2020.

8. Drioli E., Criscuoli A., Curcio E.: Membrane contactors: fundamentals, applications and potentialities. 
Elsevier, Amsterdam 2011.

9. Sengupta A., Pittman R.: Hand Book of Membrane Separations: Chemical, Pharmaceutical, Food and Biotechnological Application, CRC Presss, New York 7 (2008).

10. Pabby A. K., Sastre A. M.: J. Membr. Sci. 430, 263 (2013).

11. Drioli E., Curcio E., Di Profio G.: Chem. Eng. Res. Des. 83, 223 (2005).

12. Reed B. W., Semmens M. J., Cussler E. L., v knize: Membrane Science and Technology (Noble R. D., Stern S. A., ed.), 2. díl, str. 467. Elsevier, Amsterdam 1995.

13. Gabelman A., Hwang S.-T.: J. Membr. Sci. 159, 61 (1999).

14. Wan C. F., Yang T., Lipscomb G. G., Stookey D. J., Chung T.-S.: J. Membr. Sci. 538, 96 (2017).

15. Klaassen R., Feron P., Jansen A.: Desalination 224, 81 (2008).

16. Qi Z., Cussler E.: J. Membr. Sci. 23, 333 (1985).

17. Zaidiza D. A., Belaissaoui B., Rode S., Favre E.: Sep. Purif. Technol. 188, 38 (2017).

18. Kim B.-S., Harriott P.: J. Colloid Interface Sci. 115, 1 (1987).

19. Yuan Y., Lee T. R., v knize: Surface science techniques, str. 3. Springer, Heidelberg 2013.

20. Prasad R., Sirkar K.: AlChE J. 34, 177 (1988).

21. Ulbricht M., Lakner G., Lakner J., Belafi-Bako K.: Desalin. Water Treat. 75, 253 (2017).

22. Imai M., Furusaki S., Miyauchi T.: Ind. Eng. Chem. Process Des. Dev. 21, 421 (1982).

23. Zhu Z., Hao Z., Shen Z., Chen J.: J. Membr. Sci. 250, 269 (2005).

24. Ashrafizadeh S. N., Khorasani Z.: Chem. Eng. J. 162, 242 (2010).

25. Iversen S. B., Bhatia V. K., Dam-Johansen K., Jonsson G.: J. Membr. Sci. 130, 205 (1997).

26. Yang M. C., Cussler E.: AlChE J. 32, 1910 (1986).

27. Skiens W., Lipps B., Clark M., McLain E.: J. Biomed. Mater. Res. 5, 135 (1971).

28. Yang M.-C., Cussler E. L.: J. Membr. Sci. 42, 273 (1989).

29. Nagase K., Kohori F., Sakai K., Nishide H.: J. Membr. Sci. 254, 207 (2005).

30. Tai M., Chua I., Li K., Ng W., Teo W.: J. Membr. Sci. 87, 99 (1994).

31. Banazadeh H., Mousavi S. M.: Sep. Purif. Technol. 193, 283 (2018).

32. Gong Y., Wang Z., Wang S.: Chem. Eng. Process. 45, 652 (2006).

33. Lee Y., Noble R. D., Yeom B.-Y., Park Y.-I., Lee K.-H.: J. Membr. Sci. 194, 57 (2001).

34. Eslami S., Mousavi S. M., Danesh S., Banazadeh H.: Adv. Eng. Softw. 42, 612 (2011).

35. Iliuta I., Bougie F., Iliuta M. C.: AlChE J. 61, 955 (2015).

36. Cui Z., deMontigny D.: Carbon Manage. 4, 69 (2013).

37. Ahmadi H., Hashemifard S., Ismail A.: Chem. Eng. Res. Des. 120, 218 (2017).

38. Villeneuve K., Roizard D., Remigy J.-C., Iacono M., Rode S.: Sep. Purif. Technol. 199, 189 (2018).
39. Liang C. Z., Chung T.-S.: Sep. Purif. Technol. 202, 345 (2018).

40. Conger B. C., Barnes B. G., Sompayrac R. G., Paul H. L.: 41st International Conference on Environmental Systems, 17-21 July 2011, Portland, Oregon.

41. Semmens M. J., Qin R., Zander A.: J. - Am. Water Works Assoc. 81, 162 (1989).

42. Cooney D. O., Jackson C. C.: Chem. Eng. Commun. 79, 153 (1989).

43. Poddar T. K., Majumdar S., Sirkar K. K.: J. Membr. Sci. 120, 221 (1996).

44. Dressler M.: J. Chromatogr. A 165, 167 (1979).

45. Yun C. H., Prasad R., Sirkar K. K.: Ind. Eng. Chem. Res. 31, 1709 (1992).

46. Smith E., Hossain M. M.: Asia-Pac. J. Chem. Eng. 2, 455 (2007).

47. Lazarova Z., Syska B., Schügerl K.: J. Membr. Sci. 202, 151 (2002).

48. Đorđević J. S., Vladisavljević G. T., Trtić-Petrović T. M.: Ind. Eng. Chem. Res. 53, 4861 (2014).

49. Moreira V. R., Lebron Y. A. R., Amaral M. C. S.: Chem. Eng. J. 425, 130711 (2021).

50. Bringas E., San Román M. F., Urtiaga A. M., Ortiz I.: Int. J. Environ. Waste Manage. 9, 201 (2012).

51. Kamran Haghighi H., Irannajad M., Fortuny A., Sastre A. M.: Miner. Eng. 137, 344 (2019).

52. Laso J., García V., Bringas E., Urtiaga A. M., Ortiz I.: Ind. Eng. Chem. Res. 54, 3218 (2015).

53. Bey S., Criscuoli A., Figoli A., Leopold A., Simone S., Benamor M., Drioli E.: Desalination 264, 193 (2010).

54. Matsumoto M., Shimauchi H., Kondo K., Nakashio F.: Solvent Extr. Ion Exch. 5, 301 (1987).

55. Alexander P. R., Callahan R. W.: J. Membr. Sci. 35, 57 (1987).

56. Yun C. H., Prasad R., Guha A. K., Sirkar K. K.: Ind. Eng. Chem. Res. 32, 1186 (1993).

V. Durd'ák, M. Martinec, and R. Škarohlíd (Department of Environmental Chemistry, University of Chemistry and Technology Prague): Membrane Contactors and Their Application Potential

Nowadays, due to the scarcity of natural resources, there is more pressure on the reuse of materials and the application of circular economy principles. For this purpose, increasingly efficient and energy-saving technologies capable of extracting valuable raw materials from waste streams are needed, thus reducing energy and material dependence on primary resources. One such innovative technology is represented by membrane contactors, which enable mass sharing without the need for phase dispersion within each other, thus achieving lower operational and space requirements, as compared to conventional mass sharing devices (e.g. packed bed, tower column or stirred bed reactors). In addition, membrane contactors are very versatile and can be used not only for the recovery of valuable materials from waste streams in waste management processes (in particular recycling of metals or organ- 
ics), but also as life-saving devices in biomedical applications (e.g. as extracorporeal blood oxygenation devices).

Keywords: membrane contactors, hollow fibers, membrane extraction, membrane absorption

- Durd’ák V., Martinec M., Škarohlíd R.: Chem. Listy $116,35-41$ (2022).

- https://doi.org/10.54779/chl20220035 